\title{
Utilizing RAPD Analysis as Molecular Markers for comparison between Various Callus and Mother Plant of Jatropha curcas L.
}

\author{
Manal S. Soliman ${ }^{1}$, Khallil Elhalafawi ${ }^{2}$, Ibrahim A. Ibrahim¹, Emad Mahrous ${ }^{1}$ and Metwally \\ Bekhit $^{{ }^{*}}$ \\ ${ }^{1}$ Plant Biotechnology Dept. Genetic Engineering and Biotechnology Research Institute (GEBRI), \\ University of Sadat City, Minufiya, Egypt. \\ ${ }^{2}$ Molecular Biology Dept. Genetic Engineering and Biotechnology Research Institute (GEBRI), \\ University of Sadat City, Minufiya, Egypt. \\ *Corresponding author: E-mail: Metwally.bekhit@gebri.usc.edu.eg
}

\begin{abstract}
Calli were induced from different explants of Jatropha curcas L. seedling on MS basal agar medium in presence of different plant growth regulators. at different levels for 4 weeks Random Amplified Polymorphic DNA (RAPD) markers were used for the assessment of genetic variation of callus grown in different hormonal combinations in comparison with the mother plant. A total of 8 arbitrary sequence primers were evaluated. Of 8 primers used for the RAPD analysis, primers showed consistent band patterns. In total, scorable bands were observed with the primers. The total number of amplicons produced per primer varied from 5 for OPA- 07 and OPB- 12 to as many as 8 bands for OPB-10, OPC09 and OPR-17. The average number of bands per primer was 6.625 . Out of 53 bands, 36 were polymorphic $(67.92 \%)$. The average number of polymorphic RAPD bands was 4.5 per primer. the highest similarity (0.71) with mother plant was recorded in leaf-derived callus (S4) grown on MS solid medium with $2.5 \mu \mathrm{M}$ NAA plus $2.5 \mu \mathrm{M}$ IBA, while endosperm callus maintained on MS with hormonal combination $12.5 \mu \mathrm{M}$ IBA + BAP- $25.0 \mu \mathrm{M}$ was found to show least similarity (0.54) with mother plant. In this concern, results have been suggested to be useful fast methods for comparing of genetic changes and variation in plants.
\end{abstract}

Keywords: Jatropha curcas $L$., Callus induction, Growth regulators, RAPD analysis, Abbreviations: BAP, 6- Benzylaminopurine; IBA, indole-3-butyric acid; 2,4-D, 2,4-dichlorophenoxyacetic acid.; MS, Murashige and Skoog; RAPD, Random Amplified Polymorphic DNA.; TBE, Tris/Borate/EDTA buffer; WPM, Woody Plant Medium.

\section{INTRODUCTION}

Jatropha curcas belonging to the tribe Jatropheae in the Euphorbiaceae family is considered as an important energy plant due to its seed contains high oil content (Carels, 2009; Yang et al., 2012; Zhong-Guang Li et al., 2012). Jatropha curcas, is a perennial, deciduous and oil-bearing shrub. It is one of the most valuable crude drugs of primitive times and is still widely used in modern medicine. It has multipurpose plant valued not only for its medicinal properties and resistant to various stresses but also for its use as an oil 
seed crop (Heller, 1996 and Carels, 2009). In recent years this plant has received extensive attention of many scientists in view of its great economic importance, medicinal significant and for its seed oil as commercial source of fuel (Datta, \& Pand, 1993).

In addition, J. curcas is also widely used as folk remedy, fertilizer, soap and candle making, lighting, fish poison, watermelon mosaic virus inhibitor, and nuts collected from a non-toxic Mexican variety and consumed (Modi et al., 2006; Bisen et al., 2010; Mukherjee et al., 2011). Plant tissue culture is the method of planting explants in an artificial medium for regeneration into a new plant. Tissue culture techniques provide a fast and continuous supply of implants (Sujatha, and Mukta, 1996). This technology provides alternative solutions to problems arising from the current rate of extinction, plant loss and the ecosystem. Plant cell and tissue culture provides an alternative approach to plants that are difficult to grow, have a long planting period, or have low yields. Product yields by planting cells can produce significantly higher yields that are obtained from the components of Jatropha curcas. Nowadays focus is being placed on J. curcas callus induction and plant regeneration.

Callus induction is essential for many investigative and applied tissue culture procedures. Callus is an unorganized tissue mass that grows on a solid substrate. During the formation of callus, there is a certain degree of differentiation and changes that occur during development and specialization in morphology and metabolism. One of the main results of this differentiation is that most plant cultures lose the ability to photosynthesize.
Callus culture can also be used to initiate cell suspension, which is used in a variety of ways in plant transformation studies. Additionally, many genetic engineering protocols use callus initiation procedures after DNA is inserted into cells. The transgenic plants are then replenished from the transformed callus. In other protocols callus is created for use in biotechnological procedures such as forming cell suspension through which valuable plant products can be harvested. The growth regulators used in "in vitro" culture techniques can contribute to somaclonal variation. Generation of callus cultures involves cell adaptation to the conditions of in vitro culturing and requires changes that are beyond the reaction norm of the genome. One of the major problems of in vitro plant cultivation is the high level of somaclonal variation. The most common factors affecting soma-clonal variation are genotype, explant source, in vitro period and cultivation conditions in which the culture is established. Molecular markers as RAPD has been suggested to be useful for confirmation of genetic fidelity in plants (Ray et al., 2006). this technique has the advantages of giving reproducible results, low cost and primers can be designed without any prior knowledge of sequences (Pradeep et al., 2002). RAPD is a simple, dominant, quick and easy assay marker which requires low quantities (5-50 ng) of template DNA. RAPD markers may reveal a differential effect cytokinin/auxin on genomic DNA of callus tissues that help identify auxin and cytokinin combinations which produce more (or less) genetic variation in Jatropha callus tissues.

This study aimed to produce calli from different explants in vitro seedling-derived, to 
evaluate the variation between calli and their sources, which can also be used later in a variety of ways in plant regeneration and transformation. To achieve this purpose, Callus cultures were evaluated against mother plant by Random Amplified Polymorphic DNA (RAPD).

\section{MATERIALS AND METHOD}

\section{Plant materials}

Seeds of physic nut (Jatropha curcas) used in this study were obtained from the botanical garden of Genetic Engineering and Biotechnology Research Institute (GEBRI), University of Sadat City,

\section{In vitro Culture and incubation conditions}

Jatropha curcas seeds were used as the plant material. After removing the outer seed coat, Surface sterilization was carried out by shaking for 30 minutes with $100 \mathrm{ml}$ colorx solution (containing $5.25 \%$ sodium hypochlorite), followed by three-time washes with sterilized distilled water. Finally, disinfectant seeds were aseptically cultured for germination in glass jars on MS (Murashige and Skoog, 1962) basal agar medium, WPM (Lloyd\& Mccown,1980) and B5 (Gamborg, et al., 1968) medium without any growth regulators. All jars were sealed and labeled carefully and kept in the incubation room under complete darkness at $25 \pm 2 \circ \mathrm{C}$ for 5 days and then incubated with exposure to 1000 lux light intensity provided by cool white fluorescent lamp for 8 hours light and 16 hours dark per day for 24 days. Data were recorded at the end of incubation period as, germination \%, and visual observation.

\section{Callus induction}

for callus induction and growth, cotyledonary leaves, hypocotyl, and single node explants were isolated from seedlings, and then sectioned into segments with length $0.5 \mathrm{~cm}$ or $1 \mathrm{~cm}^{2}$ and cultured on MS
(Murashige and Skoog, 1962) basal solid medium supplemented with the different plant growth regulators for callus induction $(2.5 \mu \mathrm{M}$ $\mathrm{NAA}+2.5 \mu \mathrm{M}$ (BA) for cotyledonary leaves; (2.0 $\mu \mathrm{M} \mathrm{IBA}+2.0 \mu \mathrm{M}$ BAP) for hypocotyl; (0.5 $\mu \mathrm{M} 2,4-\mathrm{D}+25 \mu \mathrm{M} N A A$ ) for single nodes, and endosperm's medium was $12.5 \mu \mathrm{M}$ IBA +25 $\mu \mathrm{M}$ BAP as well as $50 \mathrm{mg} / \mathrm{l}$ ascorbic acid and $100 \mathrm{mg} / \mathrm{l}$ charcoal (previously selected). All cultures were incubated in growth room at $26^{\circ} \mathrm{C}$ with 16 light $/ 8$ dark daily. Subculture was carried out after 4 weeks. Data were recorded as callus formation (\%) as well as visual observation. Samples from each type of callus were prepared and stored for RAPD analysis.

\section{Statistical analysis}

Experiments were set up in a completely randomized design. Data were statistically analyzed by analysis of variance (ANOVA) using SPSS software program to detect significant differences among the mean of treatments using. Duncan's multiple range test (DMRT) at a 5\% significance level (Duncan, 1955, Snedecor and Cochran 1982).

Evaluation of variation in various callus and mother plant using molecular markers

Plant materials and DNA extraction

DNA was isolated from the four types of callus, grown on MS Agar medium supplemented with plant growth regulators as mentioned prior that was chosen previously, different explants were used from seedling 24 days-old for callus induction as hypocotyl (S1), single node (S2), endosperm (S3), 
cotyledonary leaves (S4) and leaves of the mother plant (S5). All samples (S1-S5) were analyzed by Random amplified polymorphic DNA (RAPD) for similarity to the mother plant of Jatropha curcas L.

DNA was isolated from leaf tissue samples of all varieties and all treatments

(control, drought, heat and drought+heat) at two different growth stages (four leaves and $50 \%$ flowering) using i-genomic Plant DNA Extraction MiniKit (iNtRON Biotechnology, Korea) according to their manufacturer instructions.

III.5.a. Determination of DNA concentration: DNA quantity was estimated using Nanodrop device at $260 \mathrm{~nm}$ in order to

determine DNA concentration. The final concentration of DNA was adjusted to 10 $\mathrm{ng} / \mu \mathrm{l}$

\section{Isolation and Determination of DNA} concentration:

Fresh samples (S1-S5) were frozen in liquid nitrogen and stored at $-80^{\circ} \mathrm{C}$. Total genomic DNA was isolated from all samples using (iNtRON Biotechnology, Plant DNA extraction Mini Kit, Korea) according to their manufacturer instructions (control, drought, heat and drought+heat) at two different growth stages (four leaves and 50\% flowering) using i-genomic Plant DNA Extraction Mini Kit (iNtRON Biotechnology, Korea) according to their manufacturer instructions.

III.5.a. Determination of DNA concentration: DNA quantity was estimated using Nanodrop device at 260nm in order to determine DNA concentration. The final concentration of DNA was adjusted to 10 $\mathrm{ng} / \mu \mathrm{l}$ method as described by. DNA quantity was estimated using Nanodrop device at $260 \mathrm{~nm}$. The final DNA concentrations were adjusted to $25 \mathrm{ng} / \mu \mathrm{l}$ and stored at $-20^{\circ} \mathrm{C}$.

Random amplified polymorphic DNA (RAPD)

Random amplified polymorphic DNA (RAPD) analysis was performed using eight oligonucleotide primers (OPA-07; OPA-09; OPB-10; OPB-12; OPC-09; OPR-12; OPR-17 and OPW-03. (Table, 1) PCR reactions were performed in $15 \mu$ reaction volumes containing $7.5 \mu l$ master mix (iNtRON Biotechnology, Co.), $250 \mu \mathrm{M}$ of each primer, and $100 \mathrm{ng}$ of template DNA. PCR fragment amplification was performed for 39 cycles at $94^{\circ} \mathrm{C}$ for $5 \mathrm{~min}$, $92{ }^{\circ} \mathrm{C}$ for $1 \mathrm{~min}$ and $35^{\circ} \mathrm{C}$ for $1 \mathrm{~min}$ with an initial denaturation step at $72^{\circ} \mathrm{C}$ for 2 min and a final extension step at $72^{\circ} \mathrm{C}$ for $10 \mathrm{~min}$. 
Table (1): Primers from Operon Technologies Inc. Almeda CA, USA used for RAPD analysis.

\begin{tabular}{|c|c|c|c|}
\hline S.N. & Primer & Sequence & GC\% \\
\hline 1 & OPA-7 & GAAACGGGTG & 60 \\
\hline 2 & OPA-9 & GGGTAACGCC & 70 \\
\hline 3 & OPB-10 & CTGCTGGGAC & 70 \\
\hline 4 & OPB-12 & CCTTGACGCA & 60 \\
\hline 5 & OPC-09 & CTCACCGTCC & 70 \\
\hline 6 & OPR-12 & ACAGGTGCGT & 60 \\
\hline 7 & OPR-17 & CCGTACGTAG & 60 \\
\hline 8 & OPW-03 & GTCCGGAGTG & 70 \\
\hline
\end{tabular}

\section{Data analysis}

PCR products of RAPD markers were separated on $1.5 \%$ ethidium bromide-stained agarose gels using $1 \mathrm{X}$ TBE buffer running buffer and electrophoresed at 100 volts for $1 \mathrm{~h}$. A 50 bp DNA ladder was used as indicator for DNA fragments size. Agarose gels were photographed on gel documentation system. Gels were scored as $0 / 1$ for absence/presence of DNA fragments, respectively. The total number of bands, the number of polymorphic bands and the percentage of polymorphism were calculated. Data were analyzed using cluster analysis. Similarity matrices were calculated using Jaccard coefficient (Jaccard, 1908). Dendrograms were constructed based on the UPGMA clustering method using NTSYS pc software version 2.0 (Applied Biostatistics, Setauket, New York, USA) (Rohlf, 1998)

\section{RESULTS and DISCUSSION}

\section{Germination of the seeds under in vitro conditions}

Jatropha curcas is a latex producing shrub which makes it recalcitrant for its handling in tissue culture. However, in the present study special technique was used to produce complete plantlets with welldeveloped shoots and roots from seed (fig. 1B). The cotyledons opened fully with elongation of hypocotyl and full growth of the radicle with secondary roots into the medium, by the fifth day. It was very interesting to note that the radicle did not elongate rapidly as it happens in the normal conditions, instead it was the hypocotyl that rapidly elongated. Germination percentage was significantly affected by the type of media. figure (1-a) show that, the highest mean percentage of germination was $100 \%$ and obtained from seeds germinated on WPM medium followed by B5 medium (95.00\%), while MS medium recorded the lowest percentage (88.00\%). The purpose of this experiment aims to the importance of different sources and culture medium for producing seedling with certain special properties to use it at later. 


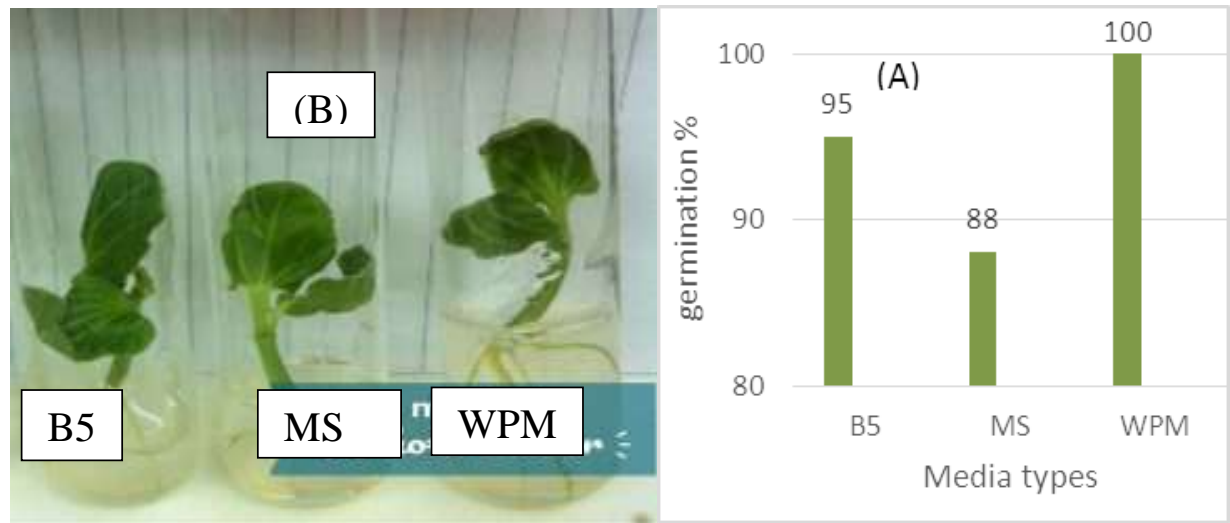

Fig. (1): Effect of medium types on (A) germination \% and (B) seedlings of Jatropha curcas $L$. after incubated for 30 days at growth room.

\section{Callus induction and growth}

Calli were produced from different explants. The culture explants gave rise to greenish compact callus. All explants responded for callus formation and no shoot formation was observed. Data in Fig., (2) showed that, endosperm-derived callus was achieved the highest formation percentage (97.72\%). Followed by single node-derived callus gave $84.72 \%$, While hypocotyl and leafderived callus were recorded $70.83 \%$ and $69.00 \%$ respectively. All calli were nonforming organs or embryoids after subculture.

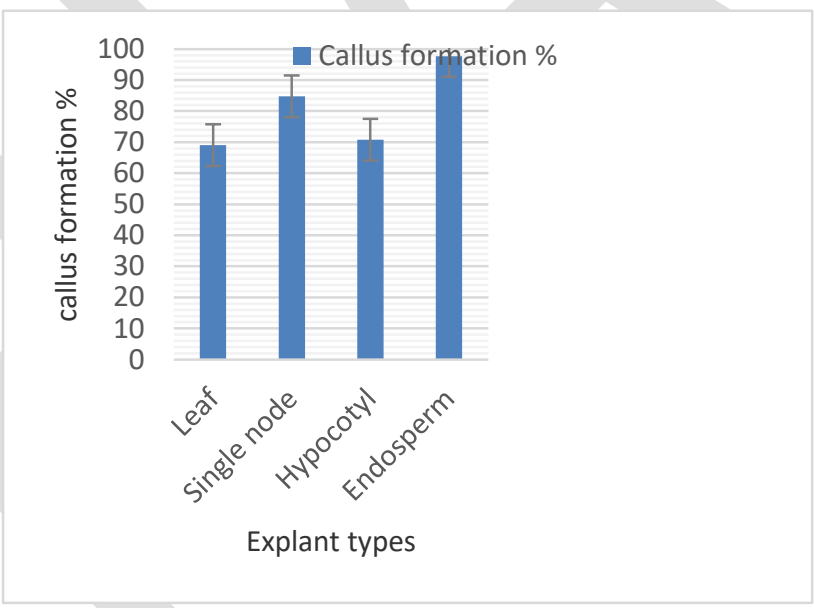

Fig., (2) Callus formation \% as affected by different explant, grown on MS, solid medium with plant growth regulators.

The percentage of callus initiation was increased by increasing the concentration of auxin 2, 4-D, at the same time the percentage of callus formation was decreased by the increase of concentration of auxin NAA, using the explants leaves and hypocotyls. There is significant difference $(P \leq 0.05)$ between two hormones NAA and 2, 4-D on the percentage of callus, (data unpublished). The auxin NAA in this study was referred to be the suitable hormone to induce callus of $\mathrm{J}$. curcas for both types of explants used. While increasing the concentration of IBA led to delay in callusing. From this result, it could be concluded that, production of callus through few days may be benefit somewhat for evaluation of variation. 
This result agreement with Nyembo, (2015) whereas, initiated in vitro callus cultures from different explants of Jatropha curcas L. on Murashige \& Skoog (1962) basal medium supplemented with growth regulator. Also, Rashida et al. (2007) initiated Callus cultures from leaf and hypocotyl of Jatropha curcas L., on Murashige \& Skoog (1962) basal medium supplemented with different growth regulator formulations. Purna et al., (2013) found that, quick callus initiation from nodes and leaves of Jatropha curcas was observed on MS basal medium with IBA plus BAP.

Evaluation of variation in various callus and mother plant using molecular markers DNA Isolation

The DNA extracted from four types of callus samples grown on MS medium with different explant types S1-S4, and mother plant (S5) were of moderate quality with absorbance at 260/280 $\mathrm{nm}$, run between 1.9 4.5.

\section{RAPD Marker analysis in callus cultures}

Of 8 primers used for the RAPD analysis, primers showed consistent band patterns. In total, scorable bands were observed with the primers (Table, 2). The total number of amplicons produced per primer varied from 5 for OPA-07, OPA-12 to as many as 8 bands for OPA-10, OPC-09 and OPR-17 (Figure, 3). The average number of bands per primer was 6.625. Out of 53 bands, 36 were polymorphic (67.92\%). The average number of polymorphic RAPD bands was 4.5 per primer. Polymerase chain reaction with RAPD primers OPA-07 and OPC-09, showed one monomorphic band in all samples (SI-S4) and in mother plant genomic DNA (S5).

Table (2): Primers used for RAPD analysis and the band characteristics obtained for the callus from different explant types (S1-S4) and mother plant (S5)

\begin{tabular}{|c|c|c|c|c|c|c|c|}
\hline \multicolumn{2}{|c|}{ Primers } & Sequences & $\begin{array}{c}\text { No.of } \\
\text { total } \\
\text { bands }\end{array}$ & $\begin{array}{c}\text { No.of } \\
\text { polymorphic } \\
\text { bands }\end{array}$ & $\begin{array}{c}\text { No. of } \\
\text { monomorphic } \\
\text { bands }\end{array}$ & $\begin{array}{c}\% \text { of } \\
\text { polymorphic } \\
\text { bands }\end{array}$ & $\begin{array}{c}\text { Total } \\
\text { bands } \\
\text { amplified }\end{array}$ \\
\hline 1 & OPA-7 & GAAACGGGTG & 5 & 4 & 1 & 80.0 & 17 \\
\hline 2 & OPA-9 & GGGTAACGCC & 6 & 3 & 3 & 50.0 & 21 \\
\hline 3 & OPB-10 & CTGCTGGGAC & 8 & 5 & 3 & 62.5 & 28 \\
\hline 4 & OPB-12 & CCTTGACGCA & 5 & 3 & 2 & 60.0 & 15 \\
\hline 5 & OPC-09 & CTCACCGTCC & 8 & 7 & 1 & 87.5 & 24 \\
\hline 6 & OPR-12 & ACAGGTGCGT & 7 & 4 & 3 & 57.14 & 25 \\
\hline 7 & OPR-17 & CCGTACGTAG & 8 & 6 & 2 & 75.0 & 27 \\
\hline 8 & OPW-03 & GTCCGGAGTG & 6 & 4 & 2 & 66.67 & 19 \\
\hline
\end{tabular}



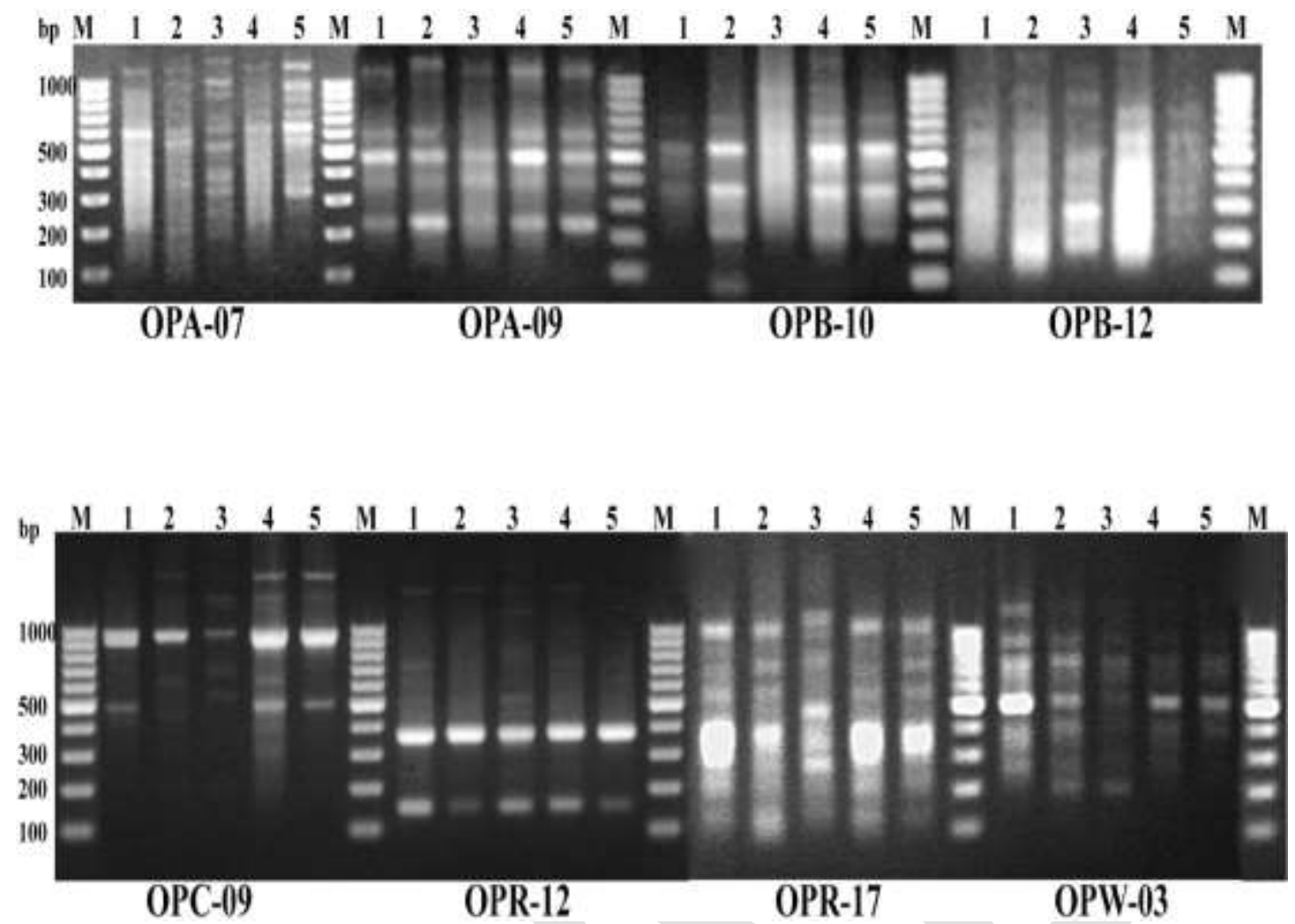

Figure (3): RAPD pattern generated by primer (a) OPA-07, (b) OPA-9. (c)OPB-10. (d) OPB-12 (e) OPC-9 (f) OPR-12 (g)OPR-17 (h) OPW-3 .Lane M -DNA marker from Chromous Biotcch (250 bp); Lanes SI — S4: Amplicons of genomic DNA obtained from callus from MS media with different explant types; Lane S5: Amplicons of genomic DNA obtained from mother plant of J. curcas L.
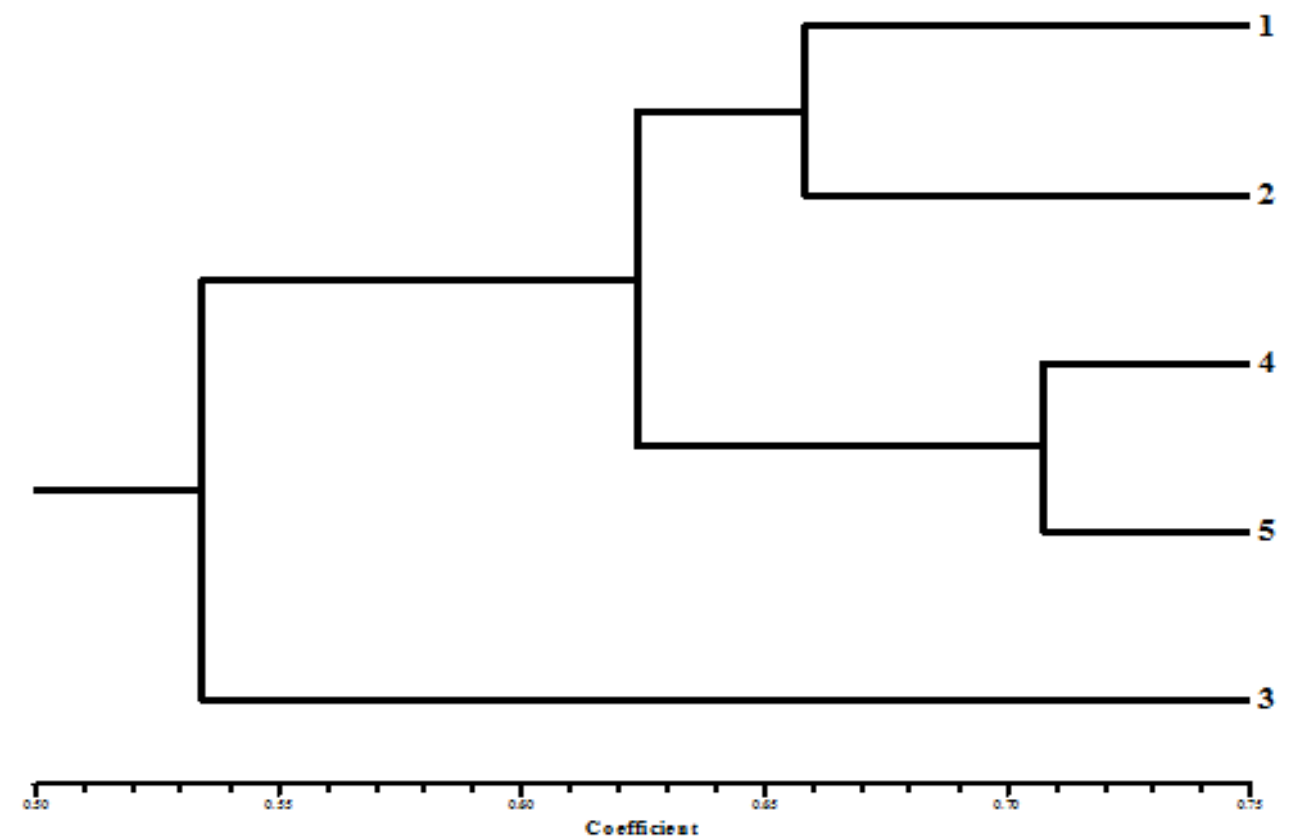

Figure (4): Dendrogram Based Nei's (1972) Genetic distance between the DNA samples of callus from MS media with different explant type and mother plant using UPGMA- Modified from NEIGHBOR procedure of PHYLIP Version 3.5. SI-S4 are the DNA samples of callus from MS media with different explant type, S5 Genomic DNA obtained from mother plant of J. curcas L. 
Considering the dendrogram (Figure, 4) constructed from the pooled data, it is evident that the set of primers chosen for the study were able to detect the influence of explant type on the callus generated. Apparently, the samples could be divided into two groups. Two samples viz., Callus resulted from leaf explant (S4) and leaf mother plant of (S5) were genetically close to each other and hence formed a group. Another distinct group is formed by hypocotyl callus (S1) and callus from single node (S2). However, callus derived from endosperm (S3) was found to be distinct from the two groups. Pairwise similarity computed for each method separately is given in Table (4). Among the callus from different samples, the highest similarity (0.71) was between callus resulted from leaf explant (S4) grown on MS solid medium with $2.5 \mu \mathrm{M}$ NAA plus $2.5 \mu \mathrm{M}$ IBA and leaf of mother plant (S5) from the in vivo and lower genetic distance between the two explants (0.29), Callus from endosperm showed the least similarity (0.54) with mother plant, while the least similarity (0.52) was between the hypocotyl-derived callus (S1) grown on MS solid medium supplemented with $2.0 \mu \mathrm{M}$ IBA plus $2.5 \mu \mathrm{M}$ BAP and callus from endosperm (S3) on MS solid medium with $12.5 \mu \mathrm{M}$ IBA and $25.0 \mu \mathrm{M}$ BAP and highest genetic distance between the two types of callus (0.48). This result agreement with Jikku Jose et al., (2012) when used RAPD markers to detect the variation in leaf disc callus cultures of Jatropha curcas, maintained in Murashige and Skoog (MS) medium with different auxin and cytokinin combinations.

Table (4): Nei's genetic identity (above diagonal) and genetic distance (below diagonal) between the DNA samples of callus from MS media with different explant types and mother plant from RAPD profile. SI-S4 are the DNA samples of callus from MS media with different explant types, S5 Genomic DNA obtained from mother plant of Jatropha curcas $L$.

\begin{tabular}{|c|c|c|c|c|c|}
\hline $\begin{array}{c}\text { DNA } \\
\text { samples }\end{array}$ & S1 & S2 & S3 & S4 & S5 \\
\hline S1 & 1.0 & 0.66 & 0.52 & 0.60 & 0.59 \\
\hline S2 & 0.34 & 1.0 & 0.54 & 0.62 & 0.68 \\
\hline S3 & 0.48 & 0.46 & 1.0 & 0.53 & 0.54 \\
\hline S4 & 0.40 & 0.38 & 0.47 & 1.0 & 0.71 \\
\hline S5 & 0.41 & 0.32 & 0.46 & 0.29 & 1.0 \\
\hline
\end{tabular}

Where, S1 is hypocotyl callus. S2, single node callus. S3, Endosperm callus. S4, leaf callus, S5, leaf of mother plant.

\section{CONCLUSION}

The sensitivity of random amplified polymorphic DNA (RAPD) using arbitrary eight oligonucleotide primers to detect genetic change in Jatropha curcas L. plants during tissue culture was assessed. RAPD analysis of callus revealed very few polymorphisms. However, RAPDs detected genetic change in callus. RAPD assessment of different explants- derived callus in jatropha plants, revealed the explant type and growth regulators are important factor for genetic change in some cases. The availability of growth hormones in the culture media regulates the genetic pattern. RAPD markers can be used to detect somaclonal variation in order to identify hormonal combinations and conditions to 
minimize the incorporation of genetic changes and to regenerate true to type plant. These results suggest that RAPDs are suitable for detecting genetic change but may not be sensitive enough to detect small changes and that minimal genetic change appears to take place in Jatropha callus. So, it is possible to use the close genetic similarity with the parent plant to obtain plants with desirable traits in the event of difficulty in micropropagation plants by direct methods.

\section{Conflicts of Interest}

The authors declare that they have no conflicts of interest.

\section{REFERENCES}

Bisen P.S., Sanodiya B.S., Thakur G.S., Baghel R.K., and Prasad GBKS., (2010). Biodiesel production with special emphasis on lipase-catalyzed transesterification. Bioltechol. Lett. 32: 1019-1030.

Carels N., (2009). Jatropha curcas: A review. Adv. Bot. Res. 50: 39-86.

Datta, S. K., Pand R. K., (1993). Applied botany abstract. 1(2):108-118.

Duncan D. B., (1955). Multiple range and multiple $F$ tests. Biometrics. 11(1):1-42.

Gamborg, O.L., Miller, R.A. and Ojima, K. (1968). Nutrient requirements of suspension cultures of soybean root cells. Exp. Cells Research, 50:151-20.

Heller J., (1996). Promoting the conservation and use of underutilized and neglected crops. 1. Physic nut Jatropha curcas L. In: International Plant Genetic Resources Institute, Rome.Pp66.

Jaccard P., (1908). Nouvelles recherches sur la distribution florale. Bull. Soc. Vaudoise Sci. Nat. 44:223-270

Jikku Jose. K. Nimisha, M.A. Anu and Padma Nambisan, (2012).
Evaluation of Somaclonal Variation in Callus Cultures of Jatropha curcas Maintained on Different Hormonal Combinations Using RAPD Markers. World Journal of Agricultural Sciences, 8 (6): 616-623.

Lloyd GB,

Mccow

B.H.,

(1980).

Commercially feasible micropropagation of mountain laurel (Kalmia latifolia) by use of shoot-tip culture. Proc Inter Plant Propagators Soc. 30: 421-437

Mawahib E.M. EINour, Rania D. M. Albasha and Badr Eldin A.E. Saeed, (2014). In Vitro callus induction of Jatropha curcas from mature seed in different auxins concentrations. International Journal of Science and Research (IJSR) Vol. 3 (6):2727-2732. (www.ijsr.net.)

Modi M.K., Reddy J.R.C., Rao BVSK, Prasad R.B.N., (2006). Lipasemediated transformation of vegetable oils into biodiesel using propan-2-ol as acyl acceptor. Biotechnol. Lett. 28: 637-640. 
Mukherjee P., Varshney A., Johnson TS, Jha TB, (2011). Jatropha curcas: a review on biotechnological status and challenges. Plant Biotechnol. Rep. 5: 197-215.

Murashige T., and Skoog F., (1962). A revised medium for rapid growth and bioassay with tobacco tissue cultures. Physiol. Plant 5: 473-479.

Nei M., (1972). Genetic distance between populations. American Naturalist, 106: 283-292.

Nyembo K., N. Mbaya, N. Muambi and C. Ilung. (2015). Establishment of Callus Derived from Jatropha curcas L. Petiole Explants and Phytochemical Screening. British Biotechnology Journal,6(3): 113-118.

Pradeep M., Sarla N., Siddiq EA., (2002). Inter simple sequence repeat (ISSR) polymorphism and its application in plant breeding. Euphytica. 128:9-17.

Rashida S., and Rabia A. M., (2007). Establishment of callus and suspension culture In Jatropha curcas Pak. J. Bot., 39(7): 2431-2441.

Ray T, Dutta I, Saha P, Das S, and Roy SC, (2006). Genetic stability of three economically important micro-propagated banana (Musa spp) cultivars of lower Indo-gangetic plains as assessed by RAPD and ISSR marker. Plant Cell Tiss. Org. cult 85:11-21

Rohlf FJ (1998). NTSYSpc. Numerical taxonomy and multivariate analysis system, version 2.02c. Exeter Software, New York.

Snedecor G.W and Cochran (1982).

Statistical methods. $7^{\text {th }}$ ED., $2^{\text {nd }}$ print, the lowa State Univ. Press, Ames, IOWA, USA.

Sujatha, M. and N. Mukta, (1996). Morphogenesis and plant regeneration from tissue culture of Jatropha curcas. Plant cell Tissue Organ. Cult., 44: 135-141.

Yang CY, Fang Z, Li Bo, Long YF, (2012). Review and prospects of Jatropha biodiesel industry in China. Renew. Sustain. Energy Rev. 16: 2178-2190.

Zhong-Guang Li, Ming Gong, Shi-Zhong Yang and Wei-Biao Long, (2012). Efficient callus induction and indirect plant regeneration from various tissues of Jatropha curcas. African Journal of Biotechnology.11 (31):78437849, Available online at http://www.academicjournals.o $\mathrm{rg} / \mathrm{AJB}$. 